\title{
A Sustainable Approach towards the Retrofit of the Public Housing Building Stock: Energy-Architectural Experimental and Numerical Analysis
}

\author{
Federica Rosso ${ }^{1,2, *} \mathbb{C}$, Arianna Peduzzi ${ }^{1}$, Lorenzo Diana ${ }^{3} \mathbb{D}$, Stefano Cascone ${ }^{4}\left(\mathbb{D}\right.$ and Carlo Cecere ${ }^{1}$ \\ 1 Department of Civil, Construction and Environmental Engineering, Sapienza University of Rome, \\ 00184 Rome, Italy; arianna.peduzzi@uniroma1.it (A.P.); carlo.cecere@uniroma1.it (C.C.) \\ 2 Department of Civil and Environmental Engineering, University of Perugia, 06123 Perugia, Italy \\ 3 Department of Civil, Construction and Environmental Engineering, University of Naples Federico II, \\ 80125 Naples, Italy; lorenzo.diana@unina.it \\ 4 Department of Civil Engineering and Architecture, University of Catania, 95125 Catania, Italy; \\ stefano.cascone@unict.it \\ * Correspondence: author: federica.rosso@uniroma1.it; Tel.: +39-06-4458-5665
}

Citation: Rosso, F.; Peduzzi, A.; Diana, L.; Cascone, S.; Cecere, C. A Sustainable Approach towards the Retrofit of the Public Housing Building Stock: Energy-Architectural Experimental and Numerical Analysis. Sustainability 2021, 13, 2881 https://doi.org/10.3390/su13052881

Academic Editor: Diego P. Ruiz

Received: 29 December 2020

Accepted: 3 March 2021

Published: 7 March 2021

Publisher's Note: MDPI stays neutral with regard to jurisdictional claims in published maps and institutional affiliations.

Copyright: (c) 2021 by the authors. Licensee MDPI, Basel, Switzerland. This article is an open access article distributed under the terms and conditions of the Creative Commons Attribution (CC BY) license (https:// creativecommons.org/licenses/by/ $4.0 /)$.

\begin{abstract}
Nowadays, energy retrofit interventions on the existing building stock are of paramount importance towards energy consumption and emissions reductions in the construction sector. Such interventions are also crucial in the view of increasing cities resilience with respect to the intensification of frequent extreme weather events, such as cold spells and heatwaves. Indeed, a wide portion of our cities is dated and lacking with respect to performances. These are the motivations behind the proposed sustainable approach, which deals with the environmental perspective, but also with social and economic ones, by proposing the retrofit of the Public Residential Building stock (Edilizia Residenziale Pubblica, ERP). The objective is to improve the energy performance of ERP stock by means of construction materials coming from local $\mathrm{km} 0$ agricultural waste and by-products. The research was conducted by means of in field and numerical analyses of the energy performances of a relevant case study building. Different layers of bio-based, recycled construction materials for the envelope were tested with respect to their efficacy in improving the energy performance of a case study building. The results demonstrate that the most performing envelope solutions and their combination are able to reduce up to $36 \%$ of the yearly energy consumption for heating.
\end{abstract}

Keywords: public housing; energy retrofit; historical stock; natural insulation elements; bio-based insulation; recycle; architectural technology; sustainability

\section{Introduction}

The built environment is responsible of high energy consumptions and, consequently, of energy-related $\mathrm{CO}_{2}$ emissions, which in Europe and the United States are mainly attributed to residential buildings [1]. Residential buildings employ energy to reach thermal comfort conditions for inhabitants in indoor spaces, both during the cold and the warm season. Therefore, because of its still unexpressed potential, it appears fundamental to act on the energy consumption reductions of residential buildings, as also indicated by European Directives (2010/31/EU) and world agreements on climate [2]. More specifically, the existing building stock is dated with respect to minimum required performances. This is true all over Europe, but especially in Southern Europe [3] and in Italy, where the 50\% of existing buildings was built before 373/76 law, which is the first law establishing the "Norms for the control of energy consumptions for thermal uses in buildings". Thus, the energy retrofit has the role of making buildings more efficient, allowing lower consumptions and lower emissions, as well as guaranteeing higher thermal comfort for their inhabitants.

Public residential building stock (Edilizia Residenziale Pubblica in Italy, referred to as ERP throughout this manuscript), which was built, especially starting after the WWI, 
has a relevant role in Europe and especially in Italy, due to the quantity of the population living there [4]. ERP has peculiar construction and architectural characteristics, such as a high level of prefabrication, industrialization and rationalization, and ERP stock is usually located in the outskirts of cities, i.e., outside the historical city centers [5]. The 9-15\% of urban population lives in ERP buildings [4], which constitutes a significant percentage of built stock in European cities and, in consideration of their current state of abandon and obsolescence, are most in need of retrofit interventions. Additionally, as evidenced by Santangelo and colleagues [6], intervening on these buildings would also allow for mitigating energy poverty, which prevents $20 \%$ of the European population adequately heating their houses, as they cannot afford the cost for acquiring energy or more efficient energy systems.

In this framework, the present work aims at developing a sustainable approach towards energy efficiency of ERP stock, under the three pillars of sustainability, namely environmental, economic, and social. Several examples in Europe in the last few decades show the evidence of public social housing retrofit strategies. Among all, in the Netherlands, several ERP stock neighbourhoods underwent huge interventions of renovation and transformation [7]: Bijlmermeer, Osdorperhof, De Leeuw van Vlandereen (Amsterdam) and Lage Lund (Rotterdam) [8] are interesting case studies, where, together with the energy retrofitting of post-WWII residential building blocks, social, environmental, and economic benefits are seen [9].

The approach delineates appropriate actions and verifies their efficacy on a relevant case study by means of experimental in field campaign and numerical analyses. Towards this energy-efficiency objective, the paper investigates the employment of passive strategies that allow for reducing energy consumptions by cutting the energy demand, while at the same time carefully considering the formal and architectural characteristics of the buildings. Indeed, passive strategies permitting properly boosting the performance of the building envelope and reducing thermal transmittance by means of different solutions that could be appropriate for the specific building.

The environmental sustainability is considered by taking into account not only energy savings, but also by choosing " $\mathrm{km0}$ " materials coming from reuse of construction and demolition waste and from agricultural waste and by-products [10]. This choice also entails a potential cost reduction for the retrofit and identification of effective strategies to contrast energy poverty. It also supports the economic and social sustainability of the approach, which aim at encouraging the regeneration of suburban neighbourhoods. The identified approach delineates an integrated process that, in consideration of the formal and architectural features of the ERP building stock, allows for an energy retrofit that not only (i) improves the energy performance of said stock, but also (ii) increases thermal comfort for the inhabitants, (iii) at a low cost, (iv) by employing adequate materials coming from reuse and recycle.

\section{Methodology}

The research is aimed at drawing an effective strategy to the integrated regeneration of the ERP stock. Such a strategy is developed here by means of a preliminary analysis of the literature regarding state-of-the-art passive strategies for the energy retrofit of the built environment, which are specifically focused on the employment of construction elements coming from recycle and reuse. After this preliminary phase, a relevant case study was chosen, which demonstrates the efficacy of the proposed integrated construction process. The case study, which was located in Rome (Italy), allowed for conducting experimental in field analyses and validating the numerical simulation of energy performance. Section 2.1 presents the relevance, suitability, and generalizability of the ERP roman case study. In Section 2.2 the experimental campaign, consisting in thermography and heat flow meter analyses is illustrated. Section 2.3 describes the results of the state-of-the-art analyses concerning natural insulation materials, and motivates the choice of the selected envelope 
strategies for the specific case study. Finally, in Section 2.4, the numerical modelling and yearly dynamic simulation, as well as its validation, are illustrated.

\subsection{The Public Housing Building Stock and the Choice of the Case Study}

Public housing in Italy represents a huge share of built environment, as underlined in previous sections. Several phases of public housing construction came in succession during the twentieth century and shape the current scenario of our cities. An early phase, at the beginning of the 20th Century, has been characterised by the urbanization of central areas that are close to the inner city, with a strong urban character and an evident coincidence between urban and building fabric. In first and second post-war phases, public housing became a tool for development and organization of increasingly peripheral areas. The wide and diversified production of public housing is made up of large interventions, which are known as real "Public Initiative Districts", and in cities, like Rome, it occupies even $12 \%$ of the total urbanized surface [4].

The strong public investment reduction in public housing sector determined for Territorial Agencies (ATER) in charge of its huge management difficulties, limited not only the construction of new buildings, but also the ordinary and extraordinary maintenance. Today these difficulties are underlined even more by the obsolescence of the building stock, lacking in reaching sufficient envelope performances. The various public housing phases are discernible from each other, not only for morphological aspects or for the relationship installed with the neighbouring city, but also for several typological and constructive features. The article focuses on the analysis of a specific case study that was built in Rome during the ' $30 \mathrm{~s}$ and it has been considered to be illustrative for public housing complexes of that period.

A huge share of public housing complexes, built in Rome in the first half of the 20th Century, is located in strategic positions of the city, in the first suburbs or even in areas that are closer to the historical center, and it is characterised by high aesthetic and typological quality and by a strong urban character. Parallel to these positive aspects, several public housing buildings show important critical issues that must be considered for retrofit interventions in the next future. These critical issues are related to the accessibility of buildings for disabled people, structural security, and energy consumption that is the focus aspect of the present research.

These historical complexes have some ideal prerogatives, for example, localization, typological and constructive features, and density, which are meant to guarantee positive effects for regeneration intervention. Such aspects validate the choice of a specific case study, chosen in the first half 20th Century public housing production, as illustrative of the applied strategy.

In the first decade of 20th Century, after the approval of the so called "Luzzatti Law" (1903), in Rome, the Institute for Council Housing (ICP) realized several interventions with a strong urban character, with medium density values. Reale in 2008 [11] defined various intervals of density that were based on the Floor Area Ratio (FAR): FAR $<0.5$ low; $0.5<$ FAR $<1.0$ medium; $1.0<$ FAR $<3.0$ high; and, FAR $>3.0$ very high. The ICP interventions of the first three decades of ' 900 shows quite often an inner court meant for the access to stairwells and compact volumes, realized on the edge of the lot.

The particular attention to typological and functional aspects together with refined constructive details determined for buildings realized in this period high quality levels, guaranteeing, even to public apartments, the privileges of bourgeois housing. The first buildings realized were the Flaminio and Trionfale complexes, while, in 1907, the construction of San Saba district began with more organic aspects then the first two. The construction of intensive interventions, with external volumes and inner courts and lot corresponding with urban block, kept on also during the '20s with various realizations (including Appio I and Flaminio II) [12].

With the beginning of the construction of Aniene Garden City and Garbatella Garden Village, the original urban model was abandoned. The urban layouts were inspired from 
the Howard's garden cities and the housing fabric was characterised by low density with apartment blocks and small houses [13].

The approval of the 1931 General Urban Plan (PRG) and fascist demolitions in the historic city caused a widespread urban sprawl: inhabitants of demolished buildings of central districts and slam dwellers of semi-central areas that were reached by urban sprawl were relocated by the Authority in outlying areas far from the centre, near to existing 19th century Fortresses, where ICP built basic necessity housing, the so-called borgate [13]. Several extensive borgate appeared, with small instant huts being built with low-cost materials in far-away areas from the centre to reduce the land cost [12]. In the same period, in contrast with this extensive approach, the ICP started the construction of Villa Pamphili and Val Melaina complexes. Both of the complexes were similar to extensive borgate for the suburban location and the general infrastructural deficiencies, but appear antithetical to them for their typological and constructive features. Both of the complexes show a distinctive urban character and display again the internal court typical of the beginning of the century and the compactness of unitary complex.

The choice of the case study falls on the Val Melaina I complex: a medium density intervention with an inner court, which is representative of public housing of the first half of the 20th Century in Rome (like Trionfale, Flaminio, Appio I, Donna Olimpia). The housing complex consists of seven-storey buildings divided into 14 stairwells that shape an impressive housing unit for about 2500 people, the so-called "Stalingrado" (Figure 1). The compact blocks are located on the edge of the lot, determining an internal court, from which is possible to access the various stairwells (Figure 1).

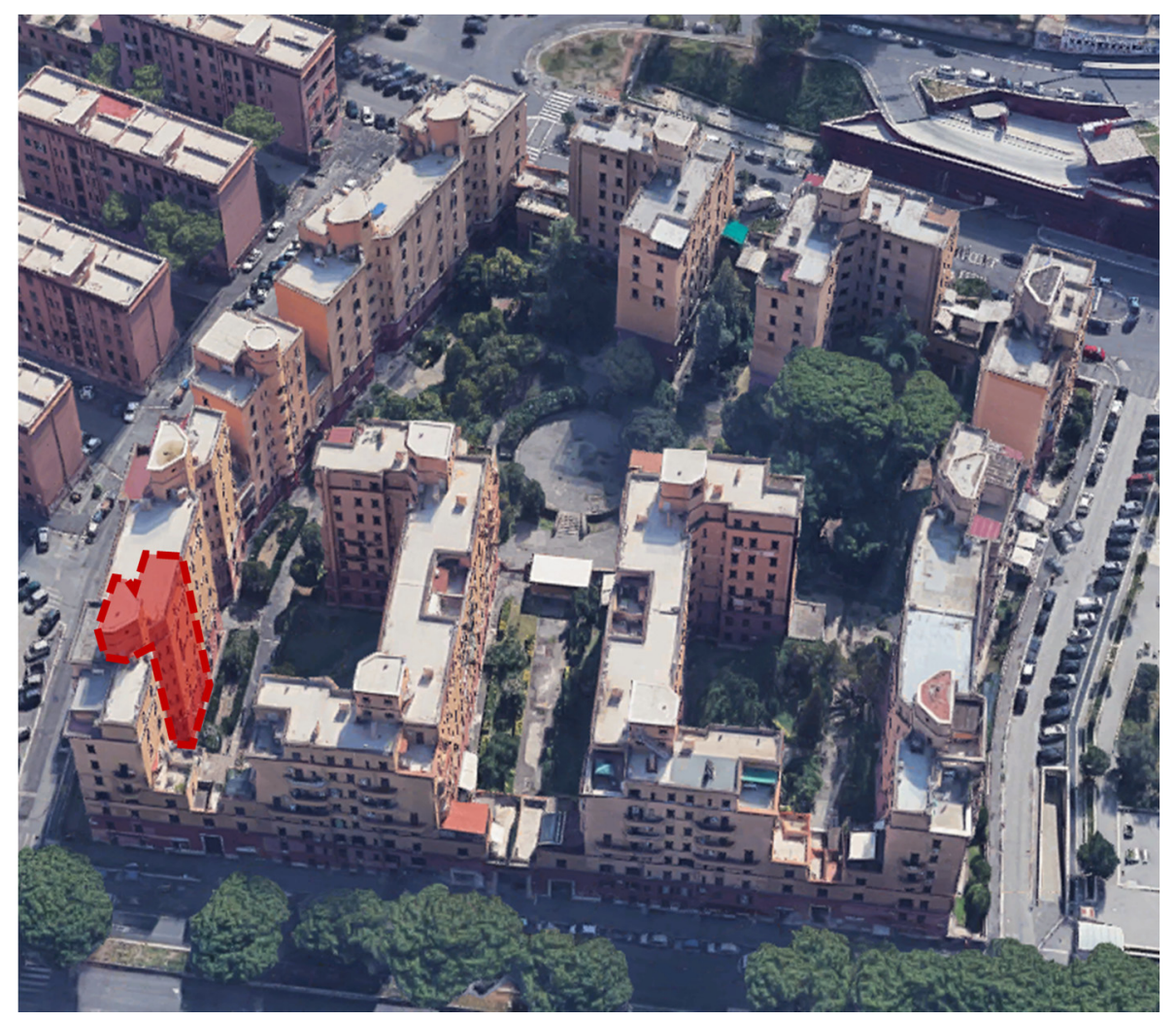

Figure 1. General view of the considered complex. In red, the modelled portion, including the considered apartment.

The stairwell volumes stand over the whole complex lightening the compactness of the phalanstery and shaping a sort of towered fortress (Figure 2). For each stairwell, five dwellings for each storey are located. Some of the dwellings are extremely small, consisting in one bedroom, one kitchen, and one narrow bathroom [12], whereas the modelled apartment type also presents a living room (Figure 3). The apartment, located at 
the sixth level, is facing prevalently South, with the exception of a small portion of the envelope, the one in correspondence to the bathroom and the kitchen, which is exposed to South-West.

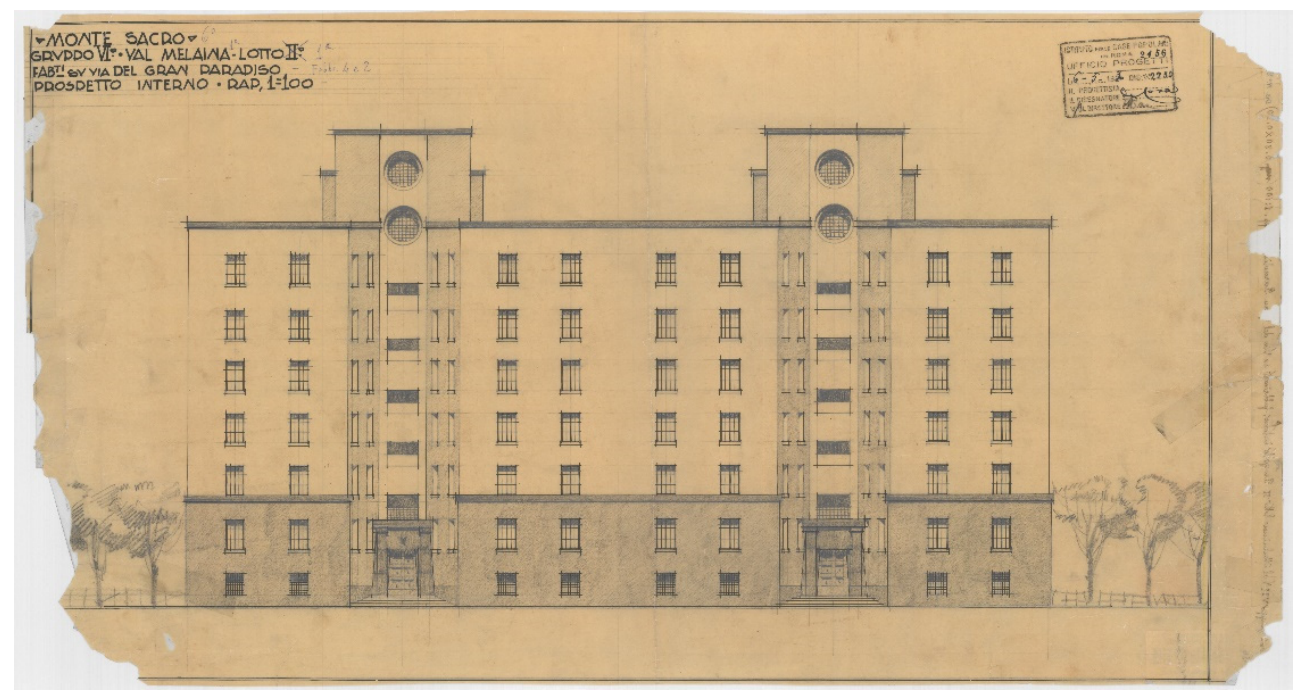

Figure 2. Original front view drawing.

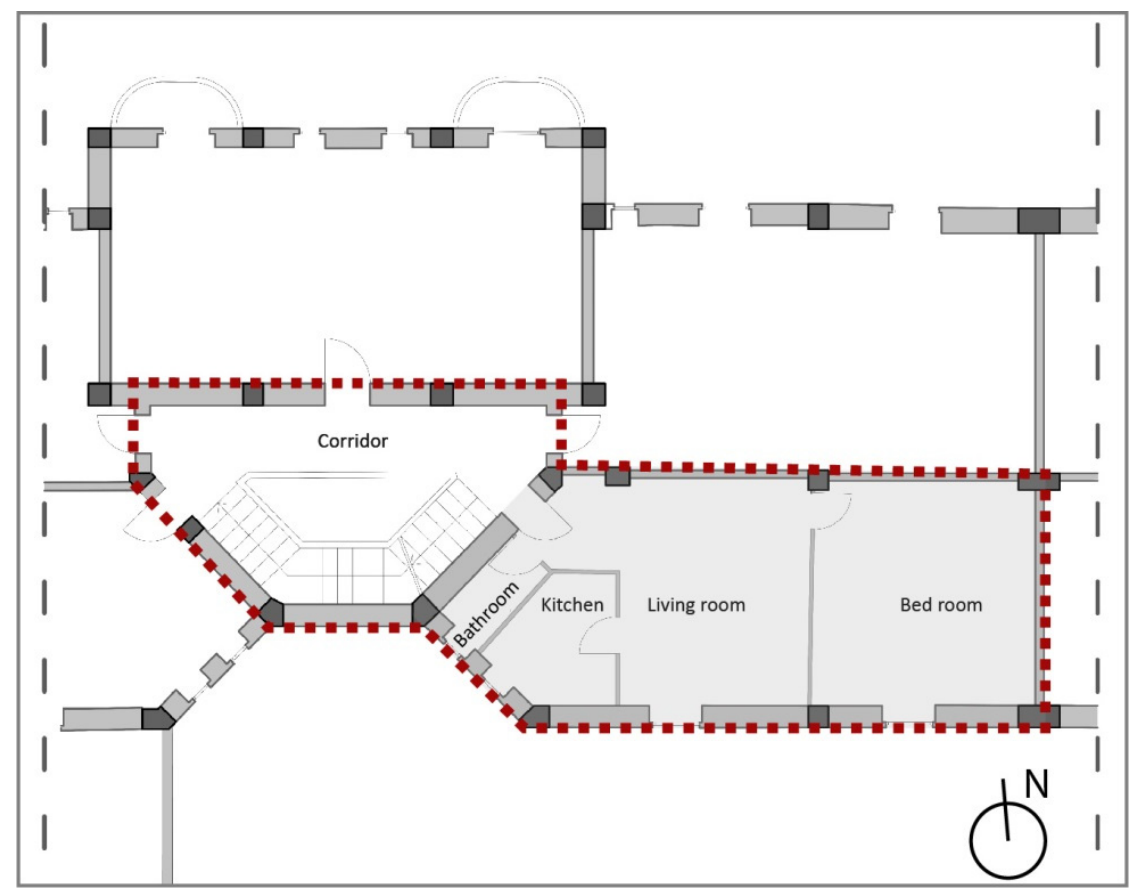

Figure 3. Apartment plan of the typical floor-modelled apartment.

The focus of the present research is to suggest an integrated approach for the regeneration of housing complexes of the first half of the last century. The main target concerns the energy retrofitting of envelopes by non-destructive technology preserving the historical and morpho-typological aspect of buildings. In order to reach this goal, the energy retrofitting is based on the application of external thermal insulation on the building envelope using recycled material coming from agricultural sector waste.

\subsection{Experimental in Field Analyses: Heat Flux Meter and Thermography}

Experimental in field campaign was conducted to understand the actual characteristics of the envelope of the case study building, on the 24 March (early spring season). In greater detail, the thermal transmittance was measured in field, by means of heat flux meter, 
in accordance with ISO 9869 standard [14]. Moreover, a thermography analysis was carried out to verify thermal bridges. The measurements were conducted during winter, in a day characterised by scarce cloudiness, when the difference between external and internal temperature was sufficient for guaranteeing the employment of the thermography instrument $[15,16]$.

\subsection{Opaque Vertical Envelope: Possible Sustainable Solutions}

In the last decade, interest in so-called "green" materials and technologies has grown exponentially. This phenomenon is attributable to an awareness and responsibility towards the environment, now threatened and altered more than ever by human activities, especially industrial ones. In this context, construction industry plays a central role, having a high impact on carbon dioxide emissions, recurring to the use of unsustainable materials, water consumption, and waste production. In the European Union alone, the construction sector is responsible for $42 \%$ of energy consumption, for more than $50 \%$ of materials extraction, for $30 \%$ of water consumption and waste production, and for $35 \%$ of greenhouse gas emissions [17].

Following this situation, numerous researches have been conducted pursuing the products and materials replacement of non-renewable raw materials, with others renewable, aiming at the consequent materials carbon footprint reduction. Consequently, considerable interest has been developed in agricultural waste (residual parts of processing, e.g., stems) coming from industrial crops to be used as building materials. Although, to date, the main fields of application of agricultural waste is animal feeding, soil fertilizing, and pellets, it has to be reported that organic fibres are appreciated in construction due to their low density, mechanical properties, biodegradability, low environmental impact, renewability, and economic convenience $[18,19]$.

Although the incorporation of bio-based materials in building products may seem to be a fairly recent phenomenon currently under study, it is actually a rediscovery. It is useful to note that there is a strong tradition in the use of plant fibres in various construction applications, particularly in the construction of vernacular and economic housing, i.e., mud bricks reinforced with straw [20] and roofs made of reed [21].

Currently, bio-based building materials find main application as insulation (Table 1), since they are characterised by high environmental performance (high specific heat capacity and low thermal conductivity) and good hygrometric behaviour [22]. Today, wood products [23], bamboo [24], straw bales [25], and other industrial crops, such as sunflower [26], corn cobs [27], hemp [28], and cotton stalks [26], or less common fibres, such as Durian or Ichu ones [29,30], are used as thermal insulation in buildings.

Sustainable insulation materials come in different forms: bales, composite panels [31], and sandwich panels [32]; among them some are binders-free [33], others are treated with sustainable glues or polymeric adhesives [34], and some others are instead used in load-bearing structures.

Although there are several high-performance natural materials that can be used as insulation, the authors' choice for the intervention hypothesized here fell on straw and hemp. This decision was dictated by the agricultural vocation of Rome and surroundings [35], and by the desire to use $\mathrm{km} 0$ materials. This decision was made to minimize intervention costs and its impact on the environment. In fact, the use of local materials, acting directly on the shortage of materials transportation journeys, presents the double advantage of reducing the greenhouse gases emissions and the costs that are directly related to the transportation itself. In addition, straw and hemp based insulation materials present another great advantage in terms of beneficial impact on the environment. In fact, straw and hemp show lower values of embodied energy, which is calculated to be around $11.28 \mathrm{MJ} / \mathrm{kg}$ for straw [36] and around $9.63 \mathrm{MJ} / \mathrm{kg}$ for hemp [37], when compared to synthetic insulation materials (e.g., mineral wool $16.6 \mathrm{MJ} / \mathrm{kg}$ [38], rock wool $16.8 \mathrm{MJ} / \mathrm{kg}$ [38], fiberglass $28 \mathrm{MJ} / \mathrm{kg}$ [38], Expanded Polystylene (EPS) $92.9 \mathrm{MJ} / \mathrm{kg}$ [38], and Polyurethane Foam (PUR) $101.5 \mathrm{MJ} / \mathrm{kg}$ [38]). 
Straw bales and hemp are among the most studied thermal insulators and building materials among the bio-based ones. Their thermal conductivity has been analysed multiple times, using experimental measurements and focusing on the analysis of the impact of fibre density and orientation with respect to the heat flux. As for the straw, it has been noted that, if the fibres are perpendicular to the flow, the thermal conductivity $(\lambda)$ is between $0.045-0.056 \mathrm{~W} / \mathrm{m} . \mathrm{K}$; whereas, if they are in a parallel direction, it is between $0.056-0.080 \mathrm{~W} / \mathrm{m} . \mathrm{K}$, showing increasing values, depending on the density of the straw bale [39]. Regarding hemp, the thermal conductivity values that were found in the experimental analyses varied from 0.039 to $0.123 \mathrm{~W} / \mathrm{m} . \mathrm{K}[28,40]$, depending on fibres direction, with lower $\lambda$ values for fibres positioned in perpendicular direction with respect to the heat flux, and higher ones for fibres in the parallel direction [41]. A further consideration concerns the fire resistance of these two materials, which is very low (category E) due to their organic origin [34]; however, it should be emphasized that the presence of natural origin binders, which are necessary for the realization of the panels, generates an increase in the fire resistance approximately around $+30 \%$ [42]. Furthermore, the combustion of such insulators does not generate the production of toxic substances, unlike many of the synthetic insulating materials.

Table 1. Overlook on studied bio-based thermal insulation materials.

\begin{tabular}{|c|c|c|c|c|}
\hline Geometry & Raw Materials & By-Products & $\begin{array}{l}\text { Recycled } \\
\text { Materials }\end{array}$ & Production Waste \\
\hline Fibrous & $\begin{array}{c}\text { Wool [43] } \\
\text { Sansevieria [10] } \\
\text { Bamboo [24] }\end{array}$ & $\begin{array}{c}\text { Straw [39] } \\
\text { Hemp [28] } \\
\text { Corn Cob [46] } \\
\text { Rice stem [34] } \\
\text { Rice husk [49] } \\
\text { Rye [51] } \\
\text { Cane [52] } \\
\text { Cotton [26] } \\
\text { Durian shell [30] } \\
\text { Coconut fibre [53] } \\
\text { Figue leaves [53] } \\
\text { Flax fibre [28] } \\
\text { Typha [54] } \\
\text { Pineapple leaves [10] } \\
\text { Peanut shell [55] } \\
\text { Walnut shell [56] } \\
\text { Date palm [57] } \\
\text { Kenaf [19] }\end{array}$ & $\begin{array}{c}\text { Paperboard [44] } \\
\text { Paper [44] } \\
\text { Textile [47] }\end{array}$ & $\begin{array}{c}\text { Sawdust [45] } \\
\text { Sunflower [26] } \\
\text { Bagasse ash [33] } \\
\text { Coffee [48] } \\
\text { Olive oil mill [50] }\end{array}$ \\
\hline Cellular & Cork [58] & & & \\
\hline
\end{tabular}

Material Choice and Hypothesis of Improvement Interventions

For the studied intervention, it was decided to act by applying a layer of external insulation aimed at improving the current wall system characteristics. The choice was motivated by the desire to carry out an intervention that was as least invasive as possible, and that did not cause excessive bother to the residents, allowing for them to stay in their apartments during the intervention on the façades. Although the application of an external layer causes a slight alteration of the original aspect of the façades, which could be possibly problematic for buildings of historical and cultural value, such as the Stalingrado complex, specific considerations must be made regarding the building itself. In fact, the complex has homogeneous plastered façades, without any artistic decoration and, consequently, the alteration resulting from the application of an external insulation layer would be minimal and not perceptible from the outside, whereas the performance improvement, as verified in this study, would be quite evident. Consequently, the choice made was justified and it was in compliance with the provisions of Legislative Decree no. 192 of 
19 August 2005, “Attuazione della direttiva 2002/91/CE relativa al rendimento energetico nell'edilizia" (Implementation of Directive 2002/91/EC relating to energy performance in buildings), and Legislative Decree 22 January 2004 n. 42, "Codice dei beni culturali e del paesaggio, ai sensi dell'articolo 10 della legge 6 luglio 2002, n. 137" (Code of cultural heritage and landscape, pursuant to article 10 of law no. 137 of 6 July 2002).

Therefore, starting from the previous considerations, two thicknesses of insulation ( 5 and $10 \mathrm{~cm}$ ) were hypothesized for both materials, as well as an additional insulation thickness $(12 \mathrm{~cm})$ analysed only with respect to hemp, which had to be applied on the external face of the wall. This operation led to the definition of the following stratigraphies:

- current infill of the building, identified with the abbreviation REF, whose stratigraphy is composed of a first layer consisting of plaster $1.5 \mathrm{~cm}$ thick, a second in tuff blocks with a thickness of $37 \mathrm{~cm}$, and an outer layer consisting of $1.5 \mathrm{~cm}$ thick plaster, and is also characterised by the presence of single-glazed wooden frames;

- improvement intervention (H5) performed with the application of a $5 \mathrm{~cm}$ layer of hemp insulation applied onto the external plaster layer, and covered with a $1.5 \mathrm{~cm}$ thick layer of plaster;

- improvement intervention (SB5) performed with the application of a $5 \mathrm{~cm}$ layer of straw insulation applied onto the external plaster layer, and covered with a $1.5 \mathrm{~cm}$ thick layer of plaster;

- improvement intervention (H10) performed with the application of a $10 \mathrm{~cm}$ layer of hemp insulation applied onto the external plaster layer, and covered with a $1.5 \mathrm{~cm}$ thick layer of plaster;

- improvement intervention (SB10) performed with the application of a $10 \mathrm{~cm}$ layer of straw insulation applied onto the external plaster layer, and covered with a $1.5 \mathrm{~cm}$ thick layer of plaster;

- improvement intervention (H12) performed with the application of a $12 \mathrm{~cm}$ layer of hemp insulation applied onto the external plaster layer, and then covered with a $1.5 \mathrm{~cm}$ thick layer of plaster.

In the modelling, straw fibres have been considered to be perpendicular to the heat flow, setting the thermal conductivity value equal to $0.055 \mathrm{~W} / \mathrm{m}$.K. Regarding hemp insulation, it has been chosen to use insulation presenting hemp fibres parallel to the heat flow, with a correspondent thermal conductivity value equal to $0.039 \mathrm{~W} / \mathrm{m} . \mathrm{K}$.

These materials choice involves another great advantage; in fact, depending on the low values of water vapour diffusivity resistance $\mu$ of the two materials, respectively, 3.9 for straw and 2.0 for hemp [39,40], they are able to be applied in contact with a material as porous as tuff, without generating condensation phenomena, therefore eliminating needing of further layers application and allowing the free vapour circulation, thus increasing internal comfort.

In addition, it was decided to hypothesize the replacement of the transparent envelope system (glass and frame), depending on the ease of this type of intervention and its diffusion among refurbishment strategies applied, even in cultural heritage buildings. A model was prepared that allowed for carrying on a comparative analysis within the current state (REF) and the intervention of windows replacing (REFW) in order to evaluate the impact of this type of intervention. The window system that was chosen for the simulation was made of low-emissivity double glazing (glass thickness $6 \mathrm{~mm}$ with an air chamber of $13 \mathrm{~mm}$ with a wooden frame). This last choice was made to maintain the historical-architectural characteristics of the building unaltered. Finally, the performance was also verified by applying both strategies, opaque envelope improvement and windows replacement, at the same time (OPTW), choosing the stratigraphy that led to the best performance among the ones previously analysed.

\subsection{Annual Dynamic Simulation and Results Validation}

The investigation of the energy performance of the proposed passive strategies was carried out in a dynamic regime for an entire year of building use by considering the 
different solutions of the retrofitted envelope, by following the previous mentioned strategy. The modelling and simulation were carried out with the software DesignBuilder [59], which is widely employed in state-of-the-art research on energy performance [60-62] (Figure 4).

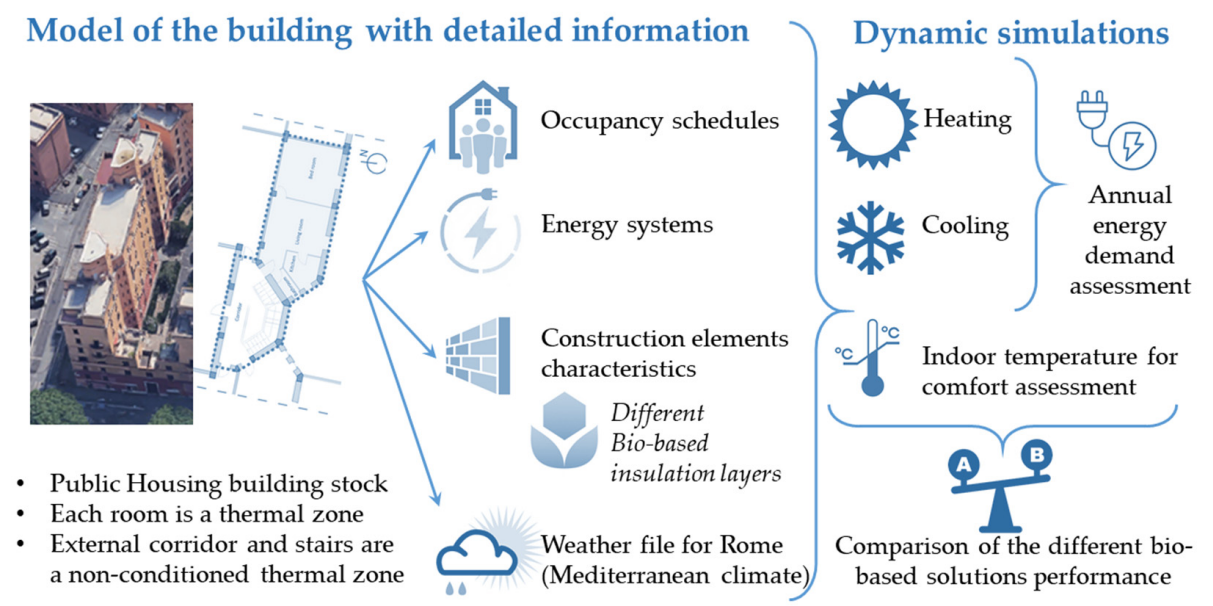

Figure 4. Flow diagram representing the synthetic methodology for the dynamic simulations.

The block of apartments referring to one stair (as indicated in Figure 1) was modelled with high level of detail, with all of the apartments composing it. The focus was then on a single apartment (Figure 3), selected as relevant and significant for energy consumptions. The energy systems of the building were based on radiator heating (fuelled by natural gas), boiler for hot water (electricity), and natural ventilation. The cooling was not present by default in the apartments, but it is possible that some inhabitants added it by means of individual initiative. In order to model the internal gains by providing a detailed occupancy schedule, we modelled many different thermal zones in the apartment (as by Figure 3), where each thermal zone corresponds to one room (bedroom, kitchen, bathroom, and living room), and then the external corridor, which is not conditioned.

Different envelope solutions were modelled and simulated, for comparative purposes: the references case (REF), which is the actual condition of the building, and the selected ameliorative cases H5, H10, SB5, SB10, REFW, and OPTW, as described in greater detail in the previous section. The simulation of the analysed apartment (Figure 3) was then validated, according to [60], by comparing the consumptions that were obtained with the simulation tool with actual ones, which were evaluated with reference to/starting from the energy bill of the apartment (see Section 3.3). The consumptions assessed starting from the validated model were then compared with each other's, in order to evaluate the effect of the proposed solutions on the energy performance of the building.

Because the focus of the present work is to compare different insulation solutions, the thermal bridges, once observed by means of thermography, were not linearly modelled for the dynamic simulation. Still, we hypothesize that, as the insulation layer was also inserted in correspondence of the thermal bridges by means of detailed architectural solutions, the addition of the insulation layer was able to solve or at least mitigate thermal bridges concerns.

Finally, as the building is in Rome, Mediterranean climate, which is classified as temperate climate with dry- and hot-summer (Csa, according to Köppen classification [63]), thus cooling-intensive, even if cooling systems are not present by default in the considered public housing complex, we verified the cooling consumptions and annual total consumptions (cooling and heating). In so doing, we hypothesized cooling systems by means of electricity. Moreover, as not all of the inhabitants would have the possibility to install cooling systems, it was crucial for the sake of social sustainability to verify that the proposed strategies were not deleterious for thermal comfort during summer. Therefore, we assessed, by means of the same simulations models without cooling systems, indoor 
mean radiant temperature $\left(\mathrm{T}_{\mathrm{mr}}\right)$ for the REF case and the optimal case, deriving from the previous energy consumption assessments. The hottest period in Rome classification [64] is between the end of July and mid-August, thus we selected 30-31 July for such simulations. The living room of the analysed apartment was considered for this purpose, and the results for the different solutions were compared.

\section{Results}

\subsection{Thermal Transmittance of the Opaque Vertical Envelope and Thermography Analyses}

The thermography analysis and assessment of thermal transmittance were conducted in the building, by following the method that is described in Section 2.2. In Figure 5, the two exemplificative thermography images evidence the presence of thermal bridges (a) in correspondence with the structural elements, (b) in the portion of the wall below and (c) above the windows. The thermal bridges are revealed by a higher temperature assessed by means of thermography, where the thermal flux is higher when compared to the other parts of the envelope. This qualitative result allows for supporting the hypotheses that an external insulation layer could be efficient in solving the thermal bridges issue, by only minimally modifying the facade.

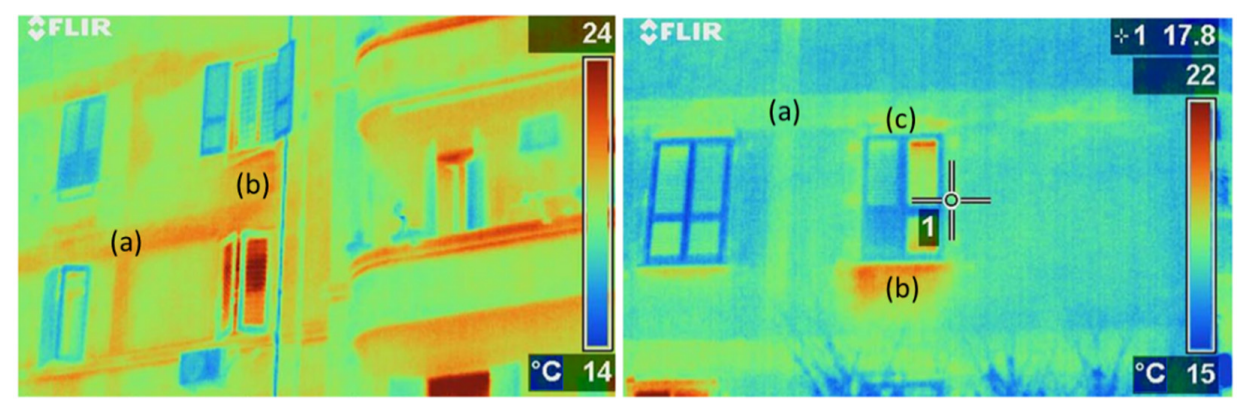

Figure 5. Thermography images of the façade. The thermal bridges are located in correspondence of (a) the structure, (b) the wall portion below the window, and (c) above the window.

With respect to in field measurement of thermal transmittance, the heat flux measured by means of the heat flux meter is reported in Figure 6, as well as the indoor and outdoor surface temperatures. The measurement campaign was conducted for three consecutive days, as by ISO 9869 [14], by placing the sensors $1.5 \mathrm{~m}$ high from the pavement. The sampling interval was $1800 \mathrm{~s}$, thus leading to 142 measurements. The mean heat flux throughout the wall was $8.73 \mathrm{~W} / \mathrm{m}^{2}$. Thermal transmittance was then calculated by dividing the measured flux by the difference between indoor and outdoor temperatures and it is equal to $1.04 \mathrm{~W} / \mathrm{m}^{2}$ for the tuff portion of the envelope.

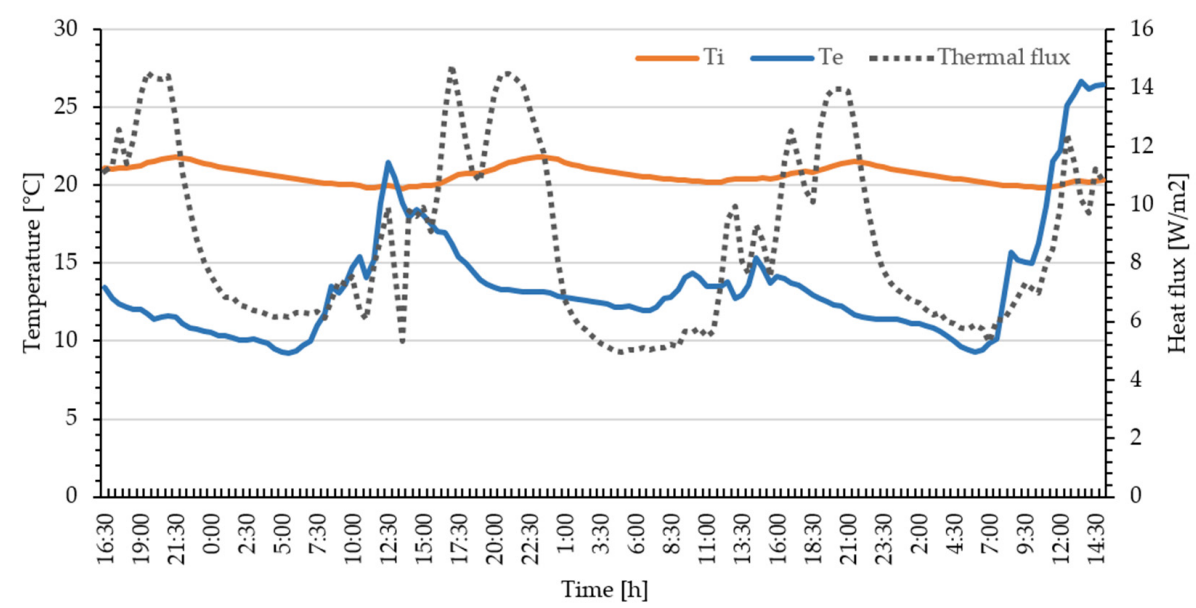

Figure 6. The heat flux measured through the wall $\left[\mathrm{W} / \mathrm{m}^{2}\right]$ and the external and internal surface temperatures $\left[{ }^{\circ} \mathrm{C}\right]$. 
The in-field campaign evidences the necessity and high potential improvement of the prospected intervention on the envelope, in order to improve the performance with respect to thermal bridges removal and the improvement of thermal transmittance value for the opaque portion of the building envelope. An additional intervention can also be envisioned on the transparent envelope system (the windows), by substituting them with more performing elements.

\subsection{Bio-Based Panel and Discontinuities Correction}

The application of the construction layers presented above consisted in hanging the insulation materials in the form of panels through the use of suitable adhesives. The panels were meant to be further secured to the rear façade by special mechanical anchoring, as is common in the state of the art. In the presence of curved elements (i.e., particular stairwells), these materials were used in the form of mats, more flexible, and therefore able to adapt the arching of these elements [56]. The use of the same material, even on the façade portions with a clear formal distinction, such as the curved stairwells, made it possible to avoid problems that are related to the different behaviour or incompatibility that could occur when two different insulating elements are paired. In addition to what discussed in Section 2.3, the direct gluing of panels to the pre-existing façade, instead of providing a ventilated coat, allows for a better behaviour of the insulation in the event of fire. In fact, avoiding the air layer made it possible to prevent any chimney effect, which would have a detrimental role in the behaviour of the material in front of fire. Finally, the application of panels and mats allowed for solving thermal bridges that are linked to the load bearing structure and the portion of envelope below the windows. Instead, it must be highlighted the attention paid to discontinuities that are constituted by balconies and cornices, which required targeted interventions. This problem is specifically a design one, which can be resolved depending on the specific solution (not only architectural, but also in terms of economic and users' impact).

For the resolution of thermal bridges due to cornices, various solutions have therefore been hypothesized: the first one, which implies a strategy of minimum intervention in terms of complexity and costs, leaves these discontinuities untouched, since they result in being minimal in terms of surface extension and occurrence. In this hypothesis, the addition of the insulating layer would decrease the overhang of the cornices with respect to the original state. These elements would still be visible due to both the remaining overhang and chromatic distinction of the plain façade finishing (ochre plaster) and the cornices one (red plaster). The second solution, on the other hand, implies a more demanding intervention in terms of complexity and costs, but allows resolving thermal discontinuities. In this second case, in fact, the removal of the cornices, the application of the panels upon the entire vertical envelope and the subsequent reconstruction of cornices replicating the preexisting ones is hypothesized. The cornice replicas are contemplated to be made by using a mix of gypsum and waste materials improving the gypsum thermal performance $[65,66]$. Despite the beneficial effect on thermal performance that the second strategy allows, it has to be taken into account that it implies a more demanding intervention in terms of complexity and costs. The cornices substitution, in fact, will imply the creation of customize gypsum replicas and specific cornices fastening that could increase the intervention cost in a sensible way.

For balconies thermal bridge resolution, the technical solutions currently existing offer a wide possibilities range, which, as mentioned above, can be adopted on different cases, depending on design choice. In the case of a soft intervention, as for the cornice, if the surface extension of the discontinuities is very small and minimal as compared to the whole façade, the hypothesis of leaving the discontinuity without resolving it could be taken into account (soft resolution). The other solutions considered belong to two main categories: (i) typological resolution, which involves a significant spatial and functional reorganization of the accommodation; and, (ii) technological resolutions, of various level of complexity. More in detail, the typological solution, which followed the example of 
Lacaton and Vassal's interventions [67] on public housing, implies the replacement of balconies with new steel elements and the incorporation of the related surface into living areas of apartments, to increase the minimum surface habitable present today. With regard to technological solutions, the balconies could also, if necessary, be disassembled and reassembled according to the gut rehabilitation technique or replaced with a new structure, while using insulated anchors [68].

It is important to emphasize that economic feasibility is encouraged by access to tax concessions for the energy requalification of Italian real estate (Superbonus 110\% [69]), which can also be enjoyed by public housing owners [70]. In greater detail, focusing on the opaque vertical envelope, the requirement to access the tax concessions for the so-called Superbonus, when considering the climate zone " $\mathrm{D}$ ", is obtaining a thermal transmittance equal or lower than $0.26 \mathrm{~W} / \mathrm{m}^{2} . \mathrm{K}$. Thus, the interventions on the envelope aimed at improving the thermo-energy performance of the envelope itself, as well as the replacement of windows system, could give access to these concessions, following the reducing consumption objectives that are desired at European level [71]. In the studied case, the results of the dynamic simulation were carried out while considering the minimum intervention options. In particular, there were no balconies in the apartment considered (Figure 3).

\subsection{Energy Performance and Validation of the Numerical Model}

The results of the energy simulation of REF case (the case corresponding to the actual situation) was compared to the actual consumptions of the same apartment (Figure 3) with respect to yearly heating consumptions. The data were taken from the energy bill for heating, where consumptions of smc (standard $\mathrm{m}^{3}$ of natural gas) for the apartment, as expressed in euros, were compared to the resulting $\mathrm{kWh}$ from the simulation. To extrapolate, from the energy bill, the smc and the $\mathrm{kWh}$ values to be compared with those of the simulation, the official price list for the reference year was employed, which is available online from the Authority for the Regulation for the Energy, Grids, and Environment (ARERA [64]). From the above-mentioned price list, the smc were found and converted into $\mathrm{kWh}$, while considering that $1 \mathrm{smc}$ corresponds to $10.69 \mathrm{kWh}$. The annual consumption of the apartment resulted in being $145.4 \mathrm{smc}$ from the energy bill. The consumption deriving from the yearly simulation resulted in being $1690.8 \mathrm{kWh}$, which is 158.2 smc. The error between the two assessments is low, corresponding to $8 \%$; therefore, we considered the model validated.

\subsection{Energy Performance and Solutions' Comparison}

Based on the simulations that were carried out, it was possible to compare the improvement feasible according to the layering used, by varying the insulating material and its thickness. This made it possible to quantify the percentage reduction in heating consumption, which was achievable through the use of the proposed solutions (Table 2).

Table 2. Monthly heating consumption $(\mathrm{kWh})$ of the studied apartment and improvement strategies percentage of savings, as numerically evaluated with the dynamic yearly simulation.

\begin{tabular}{|c|c|c|c|c|c|c|c|c|c|}
\hline Months & $\begin{array}{c}\text { REF } \\
{[k W h]}\end{array}$ & $\begin{array}{l}\text { REFW } \\
\text { [kWh] }\end{array}$ & $\begin{array}{c}\text { SB5 } \\
{[k W h]}\end{array}$ & $\begin{array}{c}\text { SB10 } \\
{[\mathrm{kWh}]}\end{array}$ & $\begin{array}{c}\text { H5 } \\
\text { [kWh] }\end{array}$ & $\begin{array}{c}\text { H10 } \\
{[\mathbf{k W h}]}\end{array}$ & $\begin{array}{c}\text { H12 } \\
{[\mathrm{kWh}]}\end{array}$ & $\begin{array}{l}\text { OPTW } \\
\text { [kWh] }\end{array}$ & $\begin{array}{c}\text { OPTW-SuB } \\
\text { [kWh] }\end{array}$ \\
\hline January & 521.6 & 501.9 & 434.5 & 396.0 & 416.3 & 379.1 & 367.4 & 356.9 & 344.9 \\
\hline February & 382.6 & 378.3 & 314.4 & 283.4 & 299.9 & 269.7 & 260.3 & 262.5 & 252.9 \\
\hline March & 213.0 & 224.1 & 164.5 & 143.8 & 154.8 & 134.5 & 128.5 & 143.2 & 136.8 \\
\hline April & 15.0 & 25.2 & 5.4 & 2.5 & 3.9 & 1.7 & 1.2 & 5.9 & 4.9 \\
\hline May-October & 0.0 & 0.0 & 0.0 & 0.0 & 0.0 & 0.0 & 0.0 & 0.0 & 0.0 \\
\hline November & 107.0 & 110.4 & 77.2 & 64.4 & 71.1 & 58.7 & 55.2 & 59.3 & 55.6 \\
\hline December & 451.5 & 429.1 & 369.8 & 335.6 & 353.6 & 320.3 & 310.0 & 295.8 & 285.2 \\
\hline TOT & 1690.8 & 1669.0 & 1365.8 & 1225.8 & 1299.6 & 1164.0 & 1122.8 & 1123.6 & 1080.4 \\
\hline SAV \% & - & $1.3 \%$ & $19.2 \%$ & $27.5 \%$ & $23.1 \%$ & $31.2 \%$ & $33.6 \%$ & $33.5 \%$ & $36.1 \%$ \\
\hline
\end{tabular}


The refurbishment intervention that led to a better result is the one involving the use of an insulation with a lower $\lambda$ value (hemp) and a greater thickness $(10 \mathrm{~cm})$, i.e., options H10 and H12. In fact, these solutions consented a significant reduction in annual consumption, which goes from $1690.8 \mathrm{kWh}$ (REF) to $1164.0 \mathrm{kWh}(\mathrm{H} 10)$, which results in a significant percentage of savings, $-31.2 \%$ for $\mathrm{H} 10$, and to $1122.8 \mathrm{kWh}$ (percentage of savings $-33.6 \%$ ) for H12.

Even the other interventions, although not as effective as the one already described, led to a significant improvement (Table 2). Specifically: (i) for the SB5 a consumption that is equal to $1365.8 \mathrm{kWh}$, and consequent saving of $-19.2 \%$; (ii) for the SB10, consumption equal to $1225.8 \mathrm{kWh}$, with a consequent saving of -27.5 ; and, (iii) for the H5 hypothesis, a consumption of $1299.6 \mathrm{kWh}$, and saving of $-23.1 \%$.

It was also interesting to compare the results that were derived from the interventions on the opaque envelope and those on the transparent one. The replacement of the glazed openings allowed for a reduction in consumption equal to $1669.0 \mathrm{kWh}$ (saving $-1.3 \%$ ), which is very low when compared with the ones achievable by intervening on the opaque envelope with any of the proposed strategies (even the less performing). It was assumed that the reason behind this poor reduction derived from the limited windows surface as compared to the total extension of the façade. For the analysed apartment, the window to wall ratio (WWR) is only $9.8 \%$ while, for the whole portion of buildings where the apartment is located, it arrives up to $13.0 \%$. As underlined by previous research [72], the replacement of windows for bad insulated exterior walls (U-value around $1.00 \mathrm{~W} / \mathrm{m}^{2} . \mathrm{K}$ ) in low-WWR buildings have a lower influence in energy savings than in the high-WWR buildings. It must be further stressed that the introduction of new double-glazing windows reduces the solar heat gain factor with a consequent reduction in energy savings, but such a tendency would be even more significant for buildings with higher WWR. Subsequently, an assessment of the achievable results was carried out by modelling an intervention on the opaque and transparent envelope at the same time. The result of this joint strategy (OPTW and OPTW-SuB as OPTW compliant with the Superbonus tax concessions), which therefore implied, respectively, the H10 and H12 stratigraphy as a solution for the opaque envelope, allows for reducing consumption by reaching $1123.6 \mathrm{kWh}$, generating savings of $-33.5 \%$ for OPTW and reaching $1080.4 \mathrm{kWh}$, determining savings of $-36.1 \%$ for OPTW-SuB.

It was also possible to assess the cost savings that were derived from the intervention. In order to calculate this value, energy consumption estimated after the modelling analysis was converted in smc, and, secondly, the current price of smc was investigated determining that, in Italy in year 2021, the price of smc will vary between $0.85-1.20 € /$ smc, depending on territorial region, gas provider, and building and apartment consumption class. A mean price $(1.03 € / \mathrm{smc})$ was used to make the evaluations in order to complete the analysis.

Initially the yearly cost of the apartment heating system in the presence of the original stratigraphy, REF, was calculated, which was found to be $162.1 €$. After this calculation, the heating system costs that were related to the different envelope layers were estimated and comparisons were made. Thus, the use of REFW stratigraphy would lead to a cost of 160.0 (-2.1 $€$ with respect to REF); solution SB5 would imply a yearly cost of $131.0 €$ $(-31.2 €$ with respect to REF); SB10 layers cost would be $115.5 €(-44.6 €$ with respect to $\mathrm{REF})$; for $\mathrm{H} 5$, the cost would be $124.6 €$ ( $-37.5 €$ with respect to REF); whereas, for H10, the cost will be equal to 111.6 ( $-50.5 €$ with respect to REF). Finally, the solution OPTW would lead to a cost of $107.7 €$, allowing a saving of $54.4 €$ per year, whereas the solution OPTW-SuB will cost $103.6 €$, allowing for a saving of $58.5 \%$ per year.

Another hypothesized advantage of the described strategy, which is strictly connected to the positioning of the insulation layer, concerns the mitigation of thermal bridges in correspondence with the building concrete structure. This potentially involves, in addition, an improvement in wall performances and an increase in internal comfort, since the radiant asymmetry of the wall system could be reduced (see the following paragraphs).

Finally, the different wall solutions transmittance values were analysed (see Figure 7). The one modelled representing the current state (REF) was equal to $1.01 \mathrm{~W} / \mathrm{m}^{2} . \mathrm{K}$. 


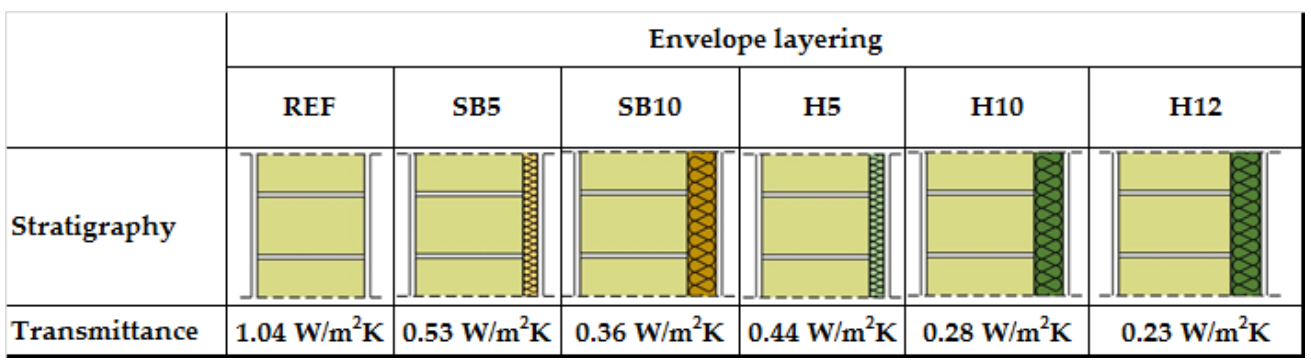

Figure 7. Layers combinations and different corresponding transmittance of the examined solutions.

The improvement interventions allowed for reaching transmittance values that were equal to $0.53 \mathrm{~W} / \mathrm{m}^{2} . \mathrm{K}$ (SB5), $0.44 \mathrm{~W} / \mathrm{m}^{2} . \mathrm{K}(\mathrm{H} 5), 0.36 \mathrm{~W} / \mathrm{m}^{2} . \mathrm{K}$ (SB10), $0.28 \mathrm{~W} / \mathrm{m}^{2} . \mathrm{K}(\mathrm{H} 10)$, and $0.23 \mathrm{~W} / \mathrm{m}^{2} . \mathrm{K}(\mathrm{H} 12)$. Because the building is located in the city of Rome, the opaque walls must comply with the transmittance limit that was provided by the legislation for climate zone $\mathrm{D}$, which is currently equal to $0.34 \mathrm{~W} / \mathrm{m}^{2} . \mathrm{K}$, and that will be reduced to $0.29 \mathrm{~W} / \mathrm{m}^{2} . \mathrm{K}$, starting from 2021. Moreover, Solution H12 complies with the requirements to achieve the tax concessions detailed in the Italian Decree 6 August 2020, "Superbonus" [69], thus opening up to a wider diffusion of the proposed solution, due to financial incentives.

Although only the $\mathrm{H} 10$ and $\mathrm{H} 12$ hypothesises were able to fulfil the regulatory limits set for 2021, it should be emphasized that, each of these interventions, even the least effective (SB5), can bring a significant improvement in the performance of the entire building.

With reference to the glazed openings, in the OPTW and OPTW-SuB interventions, the original windows, single glazing wooden framed windows, were substituted by double glazing (glazing thickness being equal to $3 \mathrm{~mm}$, air cavity thickness equal to $6 \mathrm{~mm}$ ) low emission windows with a wooden frame, in order to maintain the original aspect. The windows of the OPTW and OPTW-SuB interventions present a thermal transmittance value of $1.74 \mathrm{~W} / \mathrm{m}^{2} . \mathrm{K}$ and a solar heat gain coefficient of 0.60 . This allows for a reduction of $-58.1 \%$ with respect to the original windows performance, which was $5.89 \mathrm{~W} / \mathrm{m}^{2} . \mathrm{K}$, and also a reduction that is equal to $-30.3 \%$ of the previous coefficient of solar heat gain, which was equal to 0.86 . Therefore, the windows substitution operation will manage to satisfy not only the current legal limits $\left(2.00 \mathrm{~W} / \mathrm{m}^{2} . \mathrm{K}\right)$, but also those planned for 2021 $\left(1.80 \mathrm{~W} / \mathrm{m}^{2} . \mathrm{K}\right)$.

Finally, with respect to cooling and total energy demand, even if the public housing complex did not have cooling systems by default, but looking forward to possible future improvements, also led by individual initiatives by the inhabitants, we verified that the proposed strategies allow for saving energy also with respect to cooling, as hypothesized, thus lowering the annual energy consumptions (Table 3).

Additionally, whether or not inhabitants could not afford the addition of cooling systems, indoor mean radiant temperature was also verified to have indications regarding thermal comfort. The results show that the proposed optimal strategy (H10 and H12) are able to slightly lower $\left(-0.2^{\circ} \mathrm{C}\right) \mathrm{T}_{\mathrm{mr}}$ with respect to REF scenario (Figure 8). It is crucial to highlight that the behaviour of the inhabitants, in that matter, could further improve the thermal performance of the houses, as proper ventilation during the evening (opening the windows) could help in dispersing the accumulated heat and welcoming fresher nighttime cool air. In addition to educating inhabitants towards conscious behaviour [73], for improving resilience to extreme hot (e.g., during heatwaves), many solutions directly embedded in the building itself could encourage such actions. Allowing windows to partially open (e.g., vasistas) or inserting air openings in the movable part of the window frame are examples of these options. 
Table 3. Monthly cooling consumption and annual consumption (kWh) of the studied apartment and improvement strategies percentage of savings, as numerically evaluated with the dynamic yearly simulation.

\begin{tabular}{cccccccccc}
\hline Months & $\begin{array}{c}\text { REF } \\
{[\mathbf{k W h}]}\end{array}$ & $\begin{array}{c}\text { REFW } \\
{[\mathbf{k W h}]}\end{array}$ & $\begin{array}{c}\text { SB5 } \\
{[\mathbf{k W h}]}\end{array}$ & $\begin{array}{c}\text { SB10 } \\
{[\mathbf{k W h}]}\end{array}$ & $\begin{array}{c}\text { H5 } \\
{[\mathbf{k W h}]}\end{array}$ & $\begin{array}{c}\text { H10 } \\
{[\mathbf{k W h}]}\end{array}$ & $\begin{array}{c}\text { H12 } \\
{[\mathbf{k W h}]}\end{array}$ & $\begin{array}{c}\text { OPTW } \\
{[\mathbf{k W h}]}\end{array}$ & $\begin{array}{c}\text { OPTW-SuB } \\
{[\mathbf{k W h}]}\end{array}$ \\
\hline $\begin{array}{c}\text { January-April } \\
\text { May }\end{array}$ & 0 & 0 & 0 & 0 & 0 & 0 & 0 & 0 \\
June & -7.0 & -0.8 & -12.1 & -10.1 & -9.2 & -11.2 & -12.3 & -1.3 & -1.5 \\
July & -509.1 & -390.4 & -476.9 & -477.5 & -481.4 & -475.7 & -474.4 & -350.2 & -348.1 \\
August & -595.2 & -455.5 & -560.3 & -561.8 & -565.6 & -559.6 & -557.9 & -412.2 & -409.4 \\
September & -251.8 & -162.6 & -254.5 & -251.3 & -250.1 & -253.2 & -255.0 & -157.9 & -158.9 \\
$\begin{array}{c}\text { October } \\
\text { November- }\end{array}$ & -1.2 & 0.0 & -4.1 & -3.9 & -3.3 & -4.5 & -5.1 & -1.0 & -1.1 \\
December & 0 & 0 & 0 & 0 & 0 & 0 & 0 & 0 & 0 \\
\hline $\begin{array}{c}\text { TOT cooling } \\
\text { SAV\% }\end{array}$ & 1534.0 & 1126.7 & 1479.5 & 1475.4 & 1479.1 & 1477.1 & 1478.8 & 1034.7 & 1031.7 \\
\hline TOT annual & - & $-36.2 \%$ & $-3.7 \%$ & $-4.0 \%$ & $-3.7 \%$ & $-3.8 \%$ & $-3.7 \%$ & $-48.3 \%$ & $-48.7 \%$ \\
SAV \% & - & $-15.4 \%$ & $-13.3 \%$ & $-19.4 \%$ & $-16.1 \%$ & $-22.1 \%$ & $-24.0 \%$ & $-49.4 \%$ & $-52.7 \%$ \\
\hline
\end{tabular}

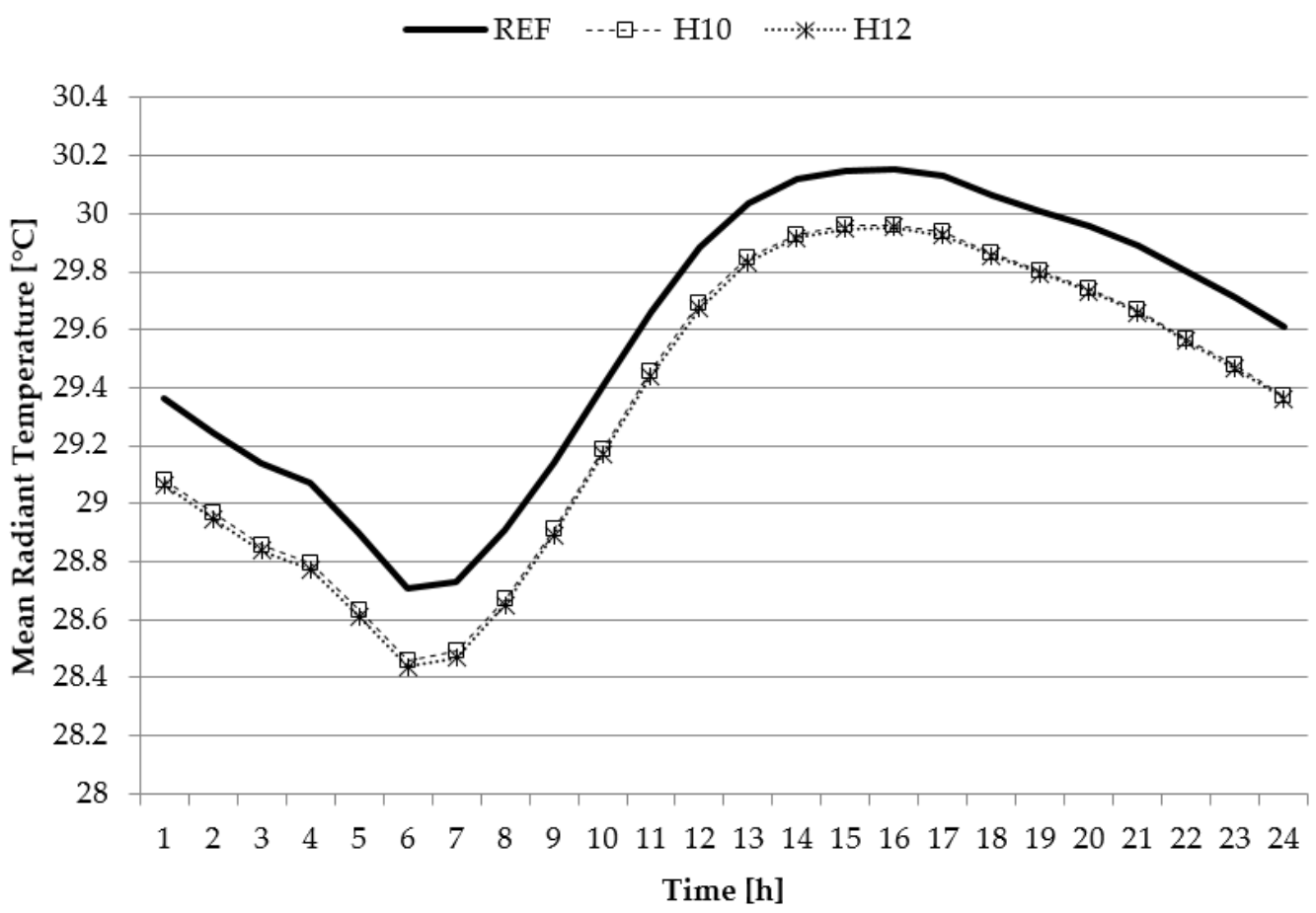

Figure 8. $\mathrm{T}_{\mathrm{mr}}$ of REF, H10, and H12 solutions, as obtained for the hourly simulation conducted for the 30 July in the living room.

\section{Conclusions}

In this article, the energy retrofit of the public housing stock (ERP) was considered. The objective of the work was to analyse sustainable solutions, from the environmental, social, and economic perspectives. Starting from these considerations, the hypothesis was to employ natural-based construction elements, deriving from production waste, by means of a non-invasive and relatively simple intervention, such as the addition of an external layer of thermal insulation. Intervention strategies were defined after analysing the state of the art with respect to natural insulation materials, which should necessarily be compatible with the specific building to be renovated. This is due to the consideration that a huge share of ERP stock is protected, due to its strong historical and cultural importance. For this reason, the considered strategies were analysed with respect to an existing, relevant the first half of 20th Century ERP case study. By means of in field experimental campaign and 
numerical simulation, which was later validated, it was possible to verify the effectiveness of the retrofit strategy with natural and $\mathrm{km} 0$ insulation materials, which allowed for significantly reducing the yearly energy consumption for heating up to the $33.6 \%$, by only intervening on the opaque envelope. Furthermore, the intervention on the opaque envelope due to the addition of an external insulation layer allows for protecting the existing walls against deterioration due to external atmospheric agents, consequently extending the life of the building.

Moreover, it was also possible to demonstrate the lower impact, for this case that is representative of same-age ERP stock, of the transparent envelope substitution, which led to saving $1.3 \%$ of heating energy with respect to the actual state. The lower significance of windows substitution is due to the low WWR in the considered apartment. For low insulated building, in the case of higher WWR, the substitution of windows would have been more effective in heating energy savings, even if the solar heat gain factor with new windows would be reduced.

Finally, the simultaneous application of insulation layer and new windows led to the higher heating energy saving, being equal to $36.1 \%$ with respect to the actual building. Such results could be expanded in the next future, by considering, for example, different positions of the insulation layer with respect to the wall and a broader range of bio-based materials and thicknesses.

In addition to evaluating heating energy, in order to maintain the considered intervention sustainable (environmentally, socially, and economically), even if cooling systems were not present by default in the considered case study, the cooling and annual energy demand were controlled for, to check whether the addition of the insulation layer would have been deleterious for the hot season; and, for indoor temperatures if no cooling system was added. The results demonstrated how the optimal solutions were able to also slightly decrease cooling energy demand (around $-4 \%$ ) with respect to REF, and to maintain slightly lower indoor temperatures in the hot season $\left(-0.2{ }^{\circ} \mathrm{C}\right)$ with respect to REF.

In future studies, ERP built in different historical periods, before and after the first energy law (n. 373 dated 1976) and seismic law (n. 64 dated 1974), should be considered, in order to analyse a wide range of sustainable strategies, which could be applied according to the different building types and technological solutions. In this work, the focus was on passive strategies, while also intervening on the energy systems could contribute in reducing consumptions, as recommended at a the global level. Finally, solutions that were based on bio-based materials in energy retrofit interventions would allow forming a virtuous circle that, from agricultural waste and by-products or from raw materials recycling, could determine the start of illustrative regeneration processes in contemporary outskirts.

Author Contributions: Conceptualization, F.R., A.P., L.D., S.C. and C.C.; methodology, F.R., A.P. and L.D.; software, F.R. and A.P.; validation, F.R., A.P. and L.D.; formal analysis, F.R., A.P. and L.D.; investigation, F.R., A.P. and L.D.; resources, F.R., A.P. and L.D.; data curation, F.R., A.P. and L.D.; writing—original draft preparation, F.R., A.P. and L.D.; writing—review and editing, F.R., A.P., L.D. and C.C.; visualization, F.R., A.P. and L.D.; supervision, F.R. and C.C.; project administration, F.R., A.P. and L.D.; funding acquisition, F.R. All authors have read and agreed to the published version of the manuscript.

Funding: The APC was funded by Sapienza University of Rome Starting Grant Type 2, grant number AR21916B891EC11C awarded to Federica Rosso (F.R.)

Acknowledgments: We gratefully acknowledge Tommaso Scrivano for the support in the in-field campaign. Federica Rosso gratefully acknowledges Ermenegildo Zegna for supporting her career through the EZ Founder's Scholarship. Federica Rosso and Arianna Peduzzi acknowledge Sapienza University for supporting their research activities with the Starting Grant.

Conflicts of Interest: The authors declare no conflict of interest. 


\section{References}

1. Berardi, U. A cross-country comparison of the building energy consumptions and their trends. Resour. Conserv. Recycl. 2016, 123, 230-241. [CrossRef]

2. United Nations Intergovernmental Panel on Climate Change. IPCC. Available online: https://www.ipcc.ch/about/ (accessed on 22 January 2019).

3. Barbosa, R.; Vicente, R.; Santos, R. Climate change and thermal comfort in Southern Europe housing: A case study from Lisbon. Build. Environ. 2015, 92, 440-451. [CrossRef]

4. Di Biagi, P.; Marchegiani, E. Città Pubbliche: Linee Guida per la Riqualificazione Urbana; Bruno Mondadori: Milano, Italy, 2008.

5. Oliveira, R.; Figueiredo, A.; Vicente, R.; Almeida, R.M.S.F. Impact of unoccupied flats on the thermal discomfort and energy demand: Case of a multi-residential building. Energy Build. 2020, 209, 109704. [CrossRef]

6. Santangelo, A.; Yan, D.; Feng, X.; Tondelli, S. Renovation strategies for the Italian public housing stock: Applying building energy simulation and occupant behaviour modelling to support decision-making process. Energy Build. 2018, 167, 269-280. [CrossRef]

7. Riccardo, F. Social Housing Renovation. Design Strategies to Improve the Quality of Declining Postwar Multifamily Blocks; LAP LAMBERT Academic Publishing: Saarbrücken, Germany, 2011.

8. Ferrante, A.; Cattani, E.; Bartolini, N.; Semprini, G. La riqualificazione energetica e architettonica del patrimonio edilizio recente. Il caso dei quartieri di edilizia residenziale pubblica. Conserv. Innov. 2012, 3, 251-276. [CrossRef]

9. Montuori, M. Good Practices for the Integrated Regeneration of Buildings. In Eco Districts, Strategies and Techniques for Urban Regeneration in Europe; Cappochin, G., Botti, M., Furlan, G., Lironi, S., Eds.; Marsilio Editori: Padova, Italy, 2014 ; pp. $192-203$.

10. Asdrubali, F.; D'Alessandro, F.; Schiavoni, S. A review of unconventional sustainable building insulation materials. Sustain. Mater. Technol. 2015, 4, 1-17. [CrossRef]

11. Reale, L. Densità, Città, Residenza. Tecniche di Densificazione e Strategie Anti-Sprawl; Gangemi: Roma, Italy, 2008.

12. Diana, L.; Scrivano, T. Le residenze universitarie come strumento per la rigenerazione degli edifici pubblici. In Residenze e Servizi per Studenti Universitari; Del Nord, R., Baratta, A.F.L., Piferi, C., Eds.; Tesis: Firenze, Italy, 2016; pp. $193-204$.

13. Villani, L. Le Borgate del Fascismo; Ledizioni: Milano, Italy, 2012.

14. ISO. ISO 9869-1:2014 Thermal Insulation-Building Elements-In-Situ Measurement of Thermal Resistance and Thermal Transmittance-Part 1: Heat Flow Meter Method. Available online: https://www.iso.org/standard/59697.html (accessed on 24 January 2021).

15. Albatici, R.; Tonelli, A.M.; Chiogna, M. A comprehensive experimental approach for the validation of quantitative infrared thermography in the evaluation of building thermal transmittance. Appl. Energy 2015, 141, 218-228. [CrossRef]

16. Lehmann, B.; Ghazi Wakili, K.; Frank, T.; Vera Collado, B.; Tanner, C. Effects of individual climatic parameters on the infrared thermography of buildings. Appl. Energy 2013, 110, 29-43. [CrossRef]

17. Commissione Europea. Roadmap to a Resource Efficient Europe; European Commission: Brussels, Belgium, 2011.

18. Rosso, F.; Pisello, A.L.; Pigliautile, I.; Cavalaglio, G.; Coccia, V. Natural, bio-based, colored linoleum: Design, preparation, characteristics and preliminary life cycle assessment. J. Clean. Prod. 2020, 267, 122202. [CrossRef]

19. Wambua, P.; Ivens, J.; Verpoest, I. Natural fibres: Can they replace glass in fibre reinforced plastics? Compos. Sci. Technol. 2003, 63, 1259-1264. [CrossRef]

20. Vatani Oskouei, A.; Afzali, M.; Madadipour, M. Experimental investigation on mud bricks reinforced with natural additives under compressive and tensile tests. Constr. Build. Mater. 2017, 142, 137-147. [CrossRef]

21. Brischke, C.; Hanske, M. Durability of untreated and thermally modified reed (Phragmites australis) against brown, white and soft rot causing fungi. Ind. Crops Prod. 2016, 91, 49-55. [CrossRef]

22. Korjenic, A.; Petránek, V.; Zach, J.; Hroudová, J. Development and performance evaluation of natural thermal-insulation materials composed of renewable resources. Energy Build. 2011, 43, 2518-2523. [CrossRef]

23. Vay, O.; De Borst, K.; Hansmann, C.; Teischinger, A.; Müller, U. Thermal conductivity of wood at angles to the principal anatomical directions. Wood Sci. Technol. 2015, 49, 577-589. [CrossRef]

24. Shah, D.U.; Bock, M.C.D.; Mulligan, H.; Ramage, M.H. Thermal conductivity of engineered bamboo composites. J. Mater. Sci. 2016, 51, 2991-3002. [CrossRef]

25. D'Alessandro, F.; Bianchi, F.; Baldinelli, G.; Rotili, A.; Schiavoni, S. Straw bale constructions: Laboratory, in field and numerical assessment of energy and environmental performance. J. Build. Eng. 2017, 11, 56-68. [CrossRef]

26. Binici, H.; Eken, M.; Dolaz, M.; Aksogan, O.; Kara, M. An environmentally friendly thermal insulation material from sunflower stalk, textile waste and stubble fibres. Constr. Build. Mater. 2014, 51, 24-33. [CrossRef]

27. Pinto, J.; Paiva, A.; Varum, H.; Costa, A.; Cruz, D.; Pereira, S.; Fernandes, L.; Tavares, P.; Agarwal, J. Corn's cob as a potential ecological thermal insulation material. Energy Build. 2011, 43, 1985-1990. [CrossRef]

28. Kymäläinen, H.R.; Sjöberg, A.M. Flax and hemp fibres as raw materials for thermal insulations. Build. Environ. 2008, 43, 1261-1269. [CrossRef]

29. Charca, S.; Noel, J.; Andia, D.; Flores, J.; Guzman, A.; Renteros, C.; Tumialan, J. Assessment of Ichu fibers as non-expensive thermal insulation system for the Andean regions. Energy Build. 2015, 108, 55-60. [CrossRef]

30. Khedari, J.; Nankongnab, N.; Hirunlabh, J.; Teekasap, S. New low-cost insulation particleboards from mixture of durian peel and coconut coir. Build. Environ. 2004, 39, 59-65. [CrossRef] 
31. Chikhi, M.; Agoudjil, B.; Boudenne, A.; Gherabli, A. Experimental investigation of new biocomposite with low cost for thermal insulation. Energy Build. 2013, 66, 267-273. [CrossRef]

32. Alavez-Ramirez, R.; Chiñas-Castillo, F.; Morales-Dominguez, V.J.; Ortiz-Guzman, M. Thermal conductivity of coconut fibre filled ferrocement sandwich panels. Constr. Build. Mater. 2012, 37, 425-431. [CrossRef]

33. Panyakaew, S.; Fotios, S. New thermal insulation boards made from coconut husk and bagasse. Energy Build. 2011, 43, 1732-1739. [CrossRef]

34. Wei, K.; Lv, C.; Chen, M.; Zhou, X.; Dai, Z.; Shen, D. Development and performance evaluation of a new thermal insulation material from rice straw using high frequency hot-pressing. Energy Build. 2015, 87, 116-122. [CrossRef]

35. Elaborazioni Ufficio di Statistica e Censimento Roma Capitale. L' Agricoltura Romana; Ledizioni: Milano, Italy, 2010.

36. Milutiene, E. House embodied energy and zero energy building concept. Environ. Res. Eng. Manag. 2010, 54, 62-71.

37. Ingrao, C.; Lo Giudice, A.; Bacenetti, J.; Tricase, C.; Dotelli, G.; Fiala, M.; Siracusa, V.; Mbohwa, C. Energy and environmental assessment of industrial hemp for building applications: A review. Renew. Sustain. Energy Rev. 2015, 51, 29-42. [CrossRef]

38. Chen, Z.; Hammad, A.W.A.; Kamardeen, I.; Akbarnezhad, A. Optimising embodied energy and thermal performance of thermal insulation in building envelopes via an automated building information modelling (BIM) tool. Buildings 2020, 10, 218. [CrossRef]

39. Costes, J.P.; Evrard, A.; Biot, B.; Keutgen, G.; Daras, A.; Dubois, S.; Lebeau, F.; Courard, L. Thermal conductivity of straw bales: Full size measurements considering the direction of the heat flow. Buildings 2017, 7, 11. [CrossRef]

40. Kirilovs, E.; Kukle, S.; Belakova, D.; Borodinecs, A.; Rucinš, Ā.; Stramkale, V. Thermal conductivity of hemp based boards. Vide. Tehnol. Resur. Environ. Technol. Resour. 2015, 1, 61-66. [CrossRef]

41. Behzad, T.; Sain, M. Measurement and prediction of thermal conductivity for hemp fiber reinforced composites. Polym. Eng. Sci. 2007, 47, 977-983. [CrossRef]

42. Palumbo, M.; Formosa, J.; Lacasta, A.M. Thermal degradation and fire behaviour of thermal insulation materials based on food crop by-products. Constr. Build. Mater. 2015, 79, 34-39. [CrossRef]

43. Zach, J.; Korjenic, A.; Petránek, V.; Hroudová, J.; Bednar, T. Performance evaluation and research of alternative thermal insulations based on sheep wool. Energy Build. 2012, 49, 246-253. [CrossRef]

44. Asdrubali, F.; Pisello, A.L.; D’Alessandro, F.; Bianchi, F.; Fabiani, C.; Cornicchia, M.; Rotili, A. Experimental and numerical characterization of innovative cardboard based panels: Thermal and acoustic performance analysis and life cycle assessment. Build. Environ. 2016, 95, 145-159. [CrossRef]

45. Cetiner, I.; Shea, A.D. Wood waste as an alternative thermal insulation for buildings. Energy Build. 2018, 168, 374-384. [CrossRef]

46. Paiva, A.; Pereira, S.; Sá, A.; Cruz, D.; Varum, H.; Pinto, J. A contribution to the thermal insulation performance characterization of corn cob particleboards. Energy Build. 2012, 45, 274-279. [CrossRef]

47. Gounni, A.; Mabrouk, M.T.; El Wazna, M.; Kheiri, A.; El Alami, M.; El Bouari, A.; Cherkaoui, O. Thermal and economic evaluation of new insulation materials for building envelope based on textile waste. Appl. Therm. Eng. 2019, 149, 475-483. [CrossRef]

48. Lachheb, A.; Allouhi, A.; El Marhoune, M.; Saadani, R.; Kousksou, T.; Jamil, A.; Rahmoune, M.; Oussouaddi, O. Thermal insulation improvement in construction materials by adding spent coffee grounds: An experimental and simulation study. J. Clean. Prod. 2019, 209, 1411-1419. [CrossRef]

49. Buratti, C.; Belloni, E.; Lascaro, E.; Merli, F.; Ricciardi, P. Rice husk panels for building applications: Thermal, acoustic and environmental characterization and comparison with other innovative recycled waste materials. Constr. Build. Mater. 2018, 171, 338-349. [CrossRef]

50. Barreca, F.; Fichera, C.R. Use of olive stone as an additive in cement lime mortar to improve thermal insulation. Energy Build. 2013, 62, 507-513. [CrossRef]

51. Bakatovich, A.; Davydenko, N.; Gaspar, F. Thermal insulating plates produced on the basis of vegetable agricultural waste. Energy Build. 2018, 180, 72-82. [CrossRef]

52. Barreca, F.; Martinez Gabarron, A.; Flores Yepes, J.A.; Pastor Pérez, J.J. Innovative use of giant reed and cork residues for panels of buildings in Mediterranean area. Resour. Conserv. Recycl. 2019, 140, 259-266. [CrossRef]

53. Hidalgo-Salazar, M.A.; Correa, J.P. Mechanical and thermal properties of biocomposites from nonwoven industrial Fique fiber mats with Epoxy Resin and Linear Low Density Polyethylene. Results Phys. 2018, 8, 461-467. [CrossRef]

54. Luamkanchanaphan, T.; Chotikaprakhan, S.; Jarusombati, S. A Study of Physical, Mechanical and Thermal Properties for Thermal Insulation from Narrow-leaved Cattail Fibers. APCBEE Procedia 2012, 1, 46-52. [CrossRef]

55. Binici, H.; Aksogan, O. Insulation material production from onion skin and peanut shell fibres, fly ash, pumice, perlite, barite, cement and gypsum. Mater. Today Commun. 2017, 10, 14-24. [CrossRef]

56. Ayrilmis, N.; Kaymakci, A.; Ozdemir, F. Physical, mechanical, and thermal properties of polypropylene composites filled with walnut shell flour. J. Ind. Eng. Chem. 2013, 19, 908-914. [CrossRef]

57. Agoudjil, B.; Benchabane, A.; Boudenne, A.; Ibos, L.; Fois, M. Renewable materials to reduce building heat loss: Characterization of date palm wood. Energy Build. 2011, 43, 491-497. [CrossRef]

58. Limam, A.; Zerizer, A.; Quenard, D.; Sallee, H.; Chenak, A. Experimental thermal characterization of bio-based materials (Aleppo Pine wood, cork and their composites) for building insulation. Energy Build. 2016, 116, 89-95. [CrossRef]

59. Design Builder. Available online: http:/ /www.designbuilder.co.uk/ (accessed on 6 March 2021).

60. Pisello, A.L.; Petrozzi, A.; Castaldo, V.L.; Cotana, F. On an innovative integrated technique for energy refurbishment of historical buildings: Thermal-energy, economic and environmental analysis of a case study. Appl. Energy 2014, 162, 1313-1322. [CrossRef] 
61. Rosso, F.; Pisello, A.L.; Cotana, F.; Ferrero, M. Cool, Translucent Natural Envelope: Thermal-optics Characteristics Experimental Assessment and Thermal-energy and Day Lighting Analysis. Energy Procedia 2017, 111, 578-587. [CrossRef]

62. Rosso, F.; Pisello, A.L.; Castaldo, V.L.; Ferrero, M.; Cotana, F. On innovative cool-colored materials for building envelopes: Balancing the architectural appearance and the thermal-energy performance in historical districts. Sustainability 2017, 9, 2319. [CrossRef]

63. Peel, M.C.; Finlayson, B.L.; McMahon, T.A. Updated world map of the Köppen-Geiger climate classification. Hydrol. Earth Syst. Sci. 2007, 11, 1633-1644. [CrossRef]

64. Salata, F.; Golasi, I.; Treiani, N.; Plos, R.; de Lieto Vollaro, A. On the outdoor thermal perception and comfort of a Mediterranean subject across other Koppen-Geiger's climate zones. Environ. Res. 2018, 167, 115-128. [CrossRef]

65. Mazhoud, B.; Collet, F.; Pretot, S.; Chamoin, J. Hygric and thermal properties of hemp-lime plasters. Build. Environ. 2016, 96, 206-216. [CrossRef]

66. Iucolano, F.; Liguori, B.; Aprea, P.; Caputo, D. Thermo-mechanical behaviour of hemp fibers-reinforced gypsum plasters. Constr. Build. Mater. 2018, 185, 256-263. [CrossRef]

67. Lacaton \& Vassal Architectes. Lacaton \& Vassal. Available online: https://www.lacatonvassal.com/ (accessed on 21 March 2020).

68. Halfen Halfen HIT. Available online: https://www.halfen.com/it/769/gamma-di-prodotti/edilizia/sistemi-di-rinforzo-earmatura/hit-sistema-a-taglio-termico-per-balconi/introduzione/ (accessed on 21 March 2020).

69. Ministero dello Sviluppo Economico; Ministero dell'Economia e delle Finanze; Ministero dell'Ambiente e della Tutela del Territorio e del Mare; Ministero delle Infrastrutture e dei Trasporti. Appendix A, Decree 6 August 2020. Requisiti Tecnici per l'accesso alle Detrazioni Fiscali per la Riqualificazione Energetica Degli Edifici_cd. Ecobonus; Gazzetta Ufficiale: Milano, Italy, 2020.

70. Agenzia Delle Entrate Riqualificazione Energetica. Available online: https://www.agenziaentrate.gov.it/portale/web/guest/ schede/agevolazioni/detrazione-riqualificazione-energetica-55-2016/per-quali-interventi (accessed on 21 March 2020).

71. Directive 2002/91/EC of the European Parliament and of the Council of 16 December 2002 on the Energy Performance of Buildings. Published in the Official Journal of the European Communities. Available online: http:/ / eur-lex.europa.eu/legalcontent/EN/TXT/?uri=CELEX\%3A32002L0091 (accessed on 4 February 2016).

72. Ahn, B.L.; Kim, J.H.; Jang, C.Y.; Leigh, S.B.; Jeong, H. Window retrofit strategy for energy saving in existing residences with different thermal characteristics and window sizes. Build. Serv. Eng. Res. Technol. 2016, 37. [CrossRef]

73. Pisello, A.L.; Rosso, F.; Castaldo, V.L.; Piselli, C.; Fabiani, C.; Cotana, F. The role of building occupants' education in their resilience to climate-change related events. Energy Build. 2017, 154, 217-231. [CrossRef] 